\title{
KARAKTERISTIK MAHASISWA BIDIK MISI PENDIDIKAN TEKNIK OTOMOTIF
}

(Studi Kasus Sikap, Minat, Motivasi, dan Prestasi Mahasiswa Bidik Misi)

\section{CHARACTERISTICS OF STUDENTS WITH "BIDIK MISI" SCHOLARSHIP IN THE DEPARTMENT OF AUTOMOTIVE ENGINEERING, YOGYAKARTA STATE UNIVERSITY}

(Case Study of Attitude, Interest, Motivation of Students with "Bidik Misi” Scholarship)

\author{
Yoga Guntur Sampurno ${ }^{1}$, Ibnu Siswanto ${ }^{2}$, Yosep Efendi ${ }^{3}$ \\ Jurusan Pendidikan Teknik Otomotif FT UNY \\ E-mail: yoga_gs@uny.ac.id
}

\begin{abstract}
ABSTRAK
Penelitian ini bertujuan untuk mendeskripsikan karakteristik dan prestasi mahasiswa bidik misi di jurusan Pendidikan Teknik Otomotif, Fakultas Teknik Universitas Negeri Yogyakarta. Subjek penelitian adalah mahasiswa bidik misi (S1 dan D3) angkatan 2012/2013 dan 2013/2014. Pengumpulan data menggunakan angket dan dokumentasi pencapaian prestasi belajar mahasiswa. Hasil penelitian menunjukkan bahwa mahasiswa bidik misi memiliki sikap, minat, dan motivasi belajar yang baik. Rerata prestasi mahassiwa bidik misi juga lebih baik dibandingkan dengan mahasiswa regular walaupun terdapat juga mahasiswa yang memiliki prestasi yang kurang. Mahasiswa-masahsiswa tersebut perlu mendapatkan perhatian dan pembinaan dari dosen supaya tidak tertinggal dibandingkan teman-teman mahasiswa satu angkatan.
\end{abstract}

Kata kunci: Sikap belajar, Minat belajar, Motivasi belajar, Prestasi, Bidik misi

\section{ABSTRACT}

This study aims to describe the characteristics and achievements of students with "Bidik Misi" scholarship in the Department of Automotive Engineering, Faculty of Engineering, Yogyakarta State University. The subjects of the study were "Bidik Misi" students (S1 dan D3) in the year of 2012/2013 and 2013/2014. The method of data collection was using questionnaires and documentation of student's achievement. The results showed that the "Bidik Misi" students have attitude, interest, and motivation to study thoroughly. The average achievement of bachelor's mission is better than regular students, although there are also students who have less achievement. These students need to get the attention and guidance from the lecturers so as not to be left behind compared to the students from the other class in the same year.

Keywords: Learning attitudes, Interest in learning, Motivation to learn, Achievement, Bidik misi

\section{PENDAHULUAN}

Setiap warga Negara berhak mendapatkan pendidikan yang layak. Hak tersebut telah dicantumkan dalam Pasal 31 (1) Undang-Undang Dasar 1945 dan ditegaskan dalam Undang-Undang No. 20 Tahun 2003 tentang Sistem Pendidikan Nasional. Berdasarkan pasal tersebut, maka pemerintah wajib memberikan layanan dan kemudahan, serta menjamin terselenggaranya pendidikan yang bermutu bagi setiap warga negara tanpa diskriminasi, dan masyarakat berkewajiban memberikan dukungan sumber daya dalam penyelenggaraan pendidikan.

Pendidikan di perguruan tinggi memerlukan biaya yang cukup besar untuk penyediaan tenaga pendidik dan sarana prasarana yang memadai (Kharisma \& Latifah, 2015; Purwanto, 2011). Padahal menurut Bapan Pusat Statistik, pada tahun 2013 masih banyak 
penduduk indonesia yang termasuk dalam golongan keluarga prasejahtera baik di daerah kota $(8,39 \%)$ dan pedesaan $(14,32 \%)$. Kondisi tersebut mempengaruhi tingkat pendidikan atau keberlanjutan pendidikan anak dari keluarga kurang mampu yang ditunjukkan oleh Angka Partisipasi Kasar (APK) ke perguruan tinggi yang baru mencapai $29,15 \%$ di tahun 2013/2014 (Kemendikbud, 2014). Oleh karena itu, setiap peserta didik pada satuan pendidikan berhak mendapatkan bantuan biaya pendidikan, khususnya bagi yang memiliki potensi akademik baik dan tidak mampu secara ekonomi serta berhak mendapatkan beasiswa bagi yang berprestasi (Satryawan, Nuridja, \& Suwena, 2016).

Pemerintah meluncurkan program pemberian beasiswa guna mendukung tercapainya pemerataan pendidikan bermutu bagi seluruh masyarakat Indonesia. Salah satu beasiswa yang diberikan yaitu program bantuan biaya pendidikan bidikmisi bagi calon mahasiswa tidak mampu secara ekonomi dan memiliki potensi akademik baik. Pemerintah berharap agar calon mashasiswa tersebut dapat menempuh pendidikan di perguruan tinggi pada program studi unggulan dan lulus tepat waktu (Waskito \& Azizah, 2013).

Pendidikan Teknik Otomotif Universitas Negeri Yogyakarta mempunyai beberapa mahasiswa yang mendapatkan beasiswa bidikmisi. Beberapa dosen yang mengajar mahasiswa bidikmisi mengungkapkan bahwa terdapat fenomena bahwa beberapa mahasiswa yang mendapatkan beasiswa bidikmisi tidak menunjukkan semangat yang tinggi dan memiliki prestasi belajar dibawah rata-rata kelas. Hal tersebut dikhawatirkan dapat mempengaruhi tujuan akhir pemberian beasiswa bidik misi untuk memberikan kesempatan kepada masyarakat dari golongan ekonomi bawah agar mendapatkan pendidikan yang baik, pekerjaan yang layak, dan akhirnya meningkatkan taraf ekonomi dan kesejahteraannya. Oleh karena itu diperlukan kajian mengenai karekteristik mahasiswa penerima beasiswa bidikmisi dan hasil belajar yang dicapai untuk mendeteksi lebih dini kemungkinan terjadinya kegagalan dalam proses pembelajaran.

\section{Karakteristik Mahasiswa}

Efendi (2011) dan Lidyasari (2016) mengartikan karakter sebagai watak (mental), kekuatan moral (moral strength), kemampuan dan kualitas yang menjadikan pembeda seseorang atau benda dengan yang lainnya (abilities and qualities). Winkel, W.S. (1999:149) menyatakan bahwa karakter ialah keseluruhan hasrat-hasrat manusia yang terarah pada suatu tujuan yang mengandung nilai moralitas, mengacu pada gaya hidup seseorang, tingkah laku yang konsisten dan lebih mudah diperkirakan. Kesimpulan dari uraian tersebut adalah bahwa karakteristik mahasiswa erat kaitannya dengan sifat dasarnya dan menunjuk pada suatu aspek dalam kepribadian yaitu keseluruhan sifat-sifat individual seseorang yang dapat memberikan pengaruh terhadap proses pembelajaran.

Ditinjau dari sifat dasar ada lima karakteristik mahasiswa dalam proses pembelajaran yaitu: (a) intelegensi, (b) sikap, (c) bakat, (d) minat, dan (e) motivasi (Syah, 1996). Namun untuk mencapai sukses, mahasiswa dituntut untuk bertekad dan berusaha agar menjadi mahasiswa yang unggul, penuh semangat dan penuh gairah mengikuti studi. Mengikuti studi secara sungguh-sungguh dengan penuh perhatian untuk membina pengetahuan ilmiah seluas-luasnya.

\section{Sikap Belajar}

Menurut Ellis (1998:141) yang memegang penting dalam sikap adalah faktor perasaan atau emosi dan reaksi/respon atau kecenderungan untuk bereaksi. Sebagai reaksi, sikap selalu berhubungan dengan dua alternatif yaitu senang (like) atau tidak senang (dislike). Selanjutnya Sarwono (1976) mengatakan bahwa sikap ini dapat bersifat positif atau bersifat negatif. Syah (1996) mengemukakan 
bahwa sikap mahasiswa yang positif terutama pada staf pengajar dan mata kuliah yang disajikan merupakan pertanda awal yang baik bagi proses pembelajaran mahasiswa.

Sikap dapat dibentuk sebagai hasil dari suatu yang dipelajari. Sikap bisa saja dipengaruhi oleh orang lain, guru dan teman. Sebaliknya sikap juga dapat dipengaruhi perbuatan dan tingkah laku seseorang (Azwar, 1998;15). Berdasarkan uraian di atas, dapat disimpulkan bahwa sikap merupakan kesiapan atau kecenderungan dalam merespon sebelum atau sewaktu melakukan tindakan atau aktivitas.

Winkel (1999) memberikan definisi belajar yang bersifat komprehensif yaitu suatu proses dari belum mampu ke arah mampu. Belajar adalah suatu aktivitas mental psikis yang berlangsung dalam integrasi aktif dengan lingkungan yang menghasilkan perubahanperubahan dalam pengetahuan, pemahaman, keterampilan, nilai-nilai dan sikap. Sedangkan Idrus (1993:5) menyatakan bahwa belajar merupakan kegiatan yang aktif dalam bentuk mengamati, memikirkan dan memahami sesuatu yang dipelajari. Selanjutnya Sardiman (1996:23) memberikan definisi belajar yaitu rangkaian kegiatan jiwa raga, psiko dan fisik, untuk menuju ke perkembangan pribadi manusia seutuhya yang berarti menyangkut unsur cipta, rasa dan karsa, ranah kognitif, afektif dan psikomotor.

Berdasarkan uraian data dapat disimpulkan bahwa sikap belajar adalah kesiapan atau kecenderungan mahasiswa dalam merespon sebelum atau sewaktu melakukan aktivitas belajar. Sikap ini dapat bersifat positif dan negatif. Selanjutnya indikator sikap mahasiswa dalam penelitian ini adalah (a) kesadaran, (b) paksaan, (c) target, (d) kebosanan, (e) kebanggaan, (f) kecenderungan, (g) pengembangan, (h) wawasan, (i) prioritas, (j) daya tarik, (k) alokasi waktu, dan (l) tantangan masa depan.

\section{Minat Belajar}

Kartono (1982) menyatakan bahwa minat adalah salah satu faktor yang ada dalam diri individu yang menunjukkan perhatian, menjadi pendorong yang lebih kuat untuk berhubungan lebih efektif dengan objek tertentu. Selanjutnya Walgito (1981:38) menyatakan bahwa minat adalah sesuatu dimana seseorang mempunyai perhatian terhadap objek tertentu yang disertai keinginan untuk mengetahui dan mempelajari serta mampu membuktikan lebih lanjut.

Winkel (1999) menjelaskan bahwa minat merupakan suatu kecenderungan jiwa yang bersifat menetap dalam diri seseorang untuk merasa senang dan tertarik kepada hal-hal tertentu. Selanjutnya Hurlock (1996) menyatakan bahwa minat merupakan sumber motivasi yang mendorong seseorang untuk melakukan apa yang mereka inginkan dan mereka bebas memilih. Apabila mereka melihat bahwa sesuatu akan menguntungkan, mereka merasa berminat untuk melakukannya, kemudian akan mendatangkan kepuasan tersendiri bagi mereka.

Kesimpulan dari uraian diatas yaitu minat adalah pemusatan perhatian serta diiringi oleh suatu usaha-usaha untuk mencapai suatu tujuan. Minat disamping bagian dari pengembangan pribadi, juga berlaku sebagai indikator dari motivasi dan sikap. Uraian di atas menunjukkan bahwa terdapat keterkaitan antara sikap dan minat. Minat pada dasarnya merupakan penerimaan akan sesuatu hubungan diri sendiri dengan sesuatu di luar diri. Semakin dekat dan kuat hubungan tersebut, maka minat akan semakin besar. Minat merupakan landasan atau fondasi bagi bangunan konsentrasi yang harus diciptakan.

Jadi, minat belajar adalah pemusatan perhatian individu terhadap objek, situasi aktivitas dan pekerjaan yang menarik perhatian dalam perubahan tingkah laku meliputi perubahan pengetahuan, sikap dan keterampilan. Berdasarkan uraian di atas dapat dirangkum bahwa indikator minat mahasiswa dalam penelitian ini adalah (a) perhatian, (b) 
kesenangan, (c) kemauan, (d) keinginan, dan (e) kepuasan.

\section{Motivasi Belajar}

Motivasi berasal dari kata Latin "movere" yang berarti dorongan atau daya penggerak. Wayne (dalam Hasibuan, 2004: 219) mengemukakan "Motivasi adalah salah satu kekuatan yang dihasilkan dari keinginan seseorang untuk memuaskan kebutuhannya". Menurut Mc. Donald (dalam Sardiman, 2004: 73) Motivasi adalah perubahan energi dalam diri seseorang yang ditandai dengan munculnya "feeling" dan didahului dengan tanggapan terhadap adanya tujuan. Menurut Danim (2004:2) motivasi memuat tiga unsur, yaitu (1) faktor, pendorong atau pembangkit motif, (2) tujuan yang ingin dicapai dan (3) strategi yang diperlukan.

Berdasarkan uraian di atas, dapat disisimpulkan bahwa motivasi adalah dorongan dan usaha yang menyebabkan terjadinya suatu perubahan energi pada diri manusia, sehingga akan mempengaruhi gejala kejiwaan, perasaan dan juga emosi kemudian bertindak atau melakukan sesuatu karena adanya tujuan, kebutuhan atau melakukan sesuatu karena adanya tujuan, kebutuhan atau keinginan yang baik. Motivasi belajar adalah keseluruhan daya penggerak di dalam diri mahasiswa yang menimbulkan kegiatan belajar, menjamin kelangsungan kegiatan belajar, dan yang memberikan arah pada kegiatan belajar, dan yang memberikan arah pada kegiatan belajar. Sehingga tujuan yang dikehendaki oleh subjek itu dapat tercapai. Dari uraian di atas dapat dirangkum bahwa indikator motivasi mahasiswa dalam penelitian ini adalah (1) tujuan, (2) keinginan, (3) semangat, (4) tantangan, (5) usaha, (6) optimis.

\section{Hasil Belajar}

Belajar merupakan proses perubahan tingkah laku akibat, adanya interaksi antara individu dengan lingkungannya. Kemampuan orang untuk belajar merupakan ciri penting yang membedakan jenisnya dari jenis-jenis makhluk lain. Hudoyono (1988: 1) menyatakan bahwa belajar merupakan perubahan tingkah laku dalam waktu yang relatif lama disertai dengan usaha oleh seseorang dari tidak mampu mengerjakan sesuatu menjadi mampu mengerjakannya. Senada dengan pendapat tersebut, Sardiman (2004: 22) mengemukakan bahwa belajar merupakan suatu usaha untuk menguasai ilmu pengetahuan menuju terbentuknya kepribadian sutuhnya. Dari kedua pendapat tersebut dapat disimpulkan bahwa belajar merupakan proses perubahan tingkah laku akibat adanya interaksi antara individu dengan lingkungannya.

Hasil belajar adalah hasil yang diperoleh dari proses belajar. Prayitno (1998: 35) mendefinisikan "hasil belajar adalah sebagai suatu yang diperoleh/dikuasai yang merupakan hasil adanya suatu proses belajar mengajar". Pendapat yang sehubungan dengan hasil belajar juga dikemukakan oleh Hamalik (1986: 21). Hasil belajar adalah tingkah yang timbul, misalnya dari tidak tahu, timbul pengertianpengertian baru perubahan dalam sikap, kebiasaan, keterampilan kesanggupan, menghargai, perkembangan sifat-sifat sosial emosional, dan pertumbuhan jasmani.

Hasil belajar adalah perubahan tingkah laku yang mencakup bidang psikolog manusia yaitu: aspek kognitif, berkembangnya kemampuan berfikir karena telah menerima berbagai macam ilmu pengetahuan; aspek afektif, berkembangnya sikap dan kepribadian dan lebih memperhatikan motorik yang dikendalikan oleh kemampuan psikologis dengan bertambahnya keterampilanketerampilan dan kecakapan-kecakapan baru, Sudjana (1989: 51).

Uraian diatas memberikan kesimpulan bahwa perubahan tingkah laku dalam diri seseorang merupakan hasil belajar yang diperoleh dari proses belajar. Adapun kesimpulan dari uraian diatas yaitu bahwa hasil belajar adalah semua bentuk perubahan individu setelah melakukan proses belajar. Perubahan ini terbentuk akibat penambahan ilmu pengetahuan, kebiasaan, sikap, motivasi, 
keterampilan dan nilai-nilai. Hasil belajar akan diketahui dengan jalan melakukan evaluasi terhadap proses interaksi belajar mengajar. Hasil evaluasi inilah yang merupakan umpan balik yang berperan sebagai indikator terhadap proses dan hasil interaksi belajar mengajar.

Proses Belajar Mengajar (PBM) merupakan suatu bentuk komunikasi antara mahasiswa dengan dosen yang didalamnya terdapat pembentukan (transform) dan pengalihan (transfer) pengetahuan, keterampilan ataupun sikap dan nilai dari dosen kepada mahasiswa sesuai dengan tujuan yang telah ditetapkan (Slameto 1991:158). Selanjutnya agar dapat mengukur dan mengetahui bahwa pembentukan dan pengalihan mendekati $100 \%$ tujuan yang dicapai, maka harus dilakukan evaluasi. Hasil dari evaluasi diperoleh penilaian yang merupakan bagian integral dari proses belajar mengajar.

Penilaian dan evaluasi juga berperan untuk mengetahui relevansi materi dan pengalaman belajar mengajar terhadap tujuan. Hasil penilaian ini bermanfaat untuk feed back bagi perbaikan pengajaran selanjutnya. Dengan demikian dapat disimpulkan bahwa pada dasarnya tujuan dilakukan evaluasi adalah untuk mengetahui keberhasilan penyelenggaraan akademik yang meliputi keberhasilan mahasiswa, keberhasilan dosen dalam mengajar dan keberhasilan program pengajaran tersebut.

Hasil penilaian dari keberhasilan belajar mahasiswa di FT UNY, biasanya dinyatakan dalam bentuk alfabetis dan angka-angka. Penilaian biasanya difokuskan pada penguasaan, keterampilan yang diajarkan dalam mata kuliah. Sumber penilaian terhadap indeks prestasi (IP) mahasiswa berdasarkan tugas struktur, ujian mid semester, dan kehadiran kuliah.

\section{METODE PENELITIAN}

Jenis Penelitian

Penelitian ini termasuk penelitian deskriptif komparatif yang bertujuan untuk mendekripsikan perbedaan karakteristik dan hasil belajar antara mahasiswa reguler dan mahasiswa bidik misi pada jurusan Teknik Otomotif FT UNY program Pendidikan Teknik Otomotif.

\section{Subyek Penelitian}

Subyek penelitian ini adalah Seluruh mahasiswa bidik misi jurusan Pendidikan Teknik Otomotif FT UNY S1 dan D3 tahun I dan II sejumlah 56 mahasiswa dan mahasiswa non bidik misi pada tahun yang sama.

Teknik Pengumpulan Data

Data yang digunakan dalam penelitian ini terdiri data sekunder berupa hasil belajar mahasiswa dan data primer tentang karakteristik mahasiswa. Teknik pengumpulan data pada penelitian ini menggunakan angket dan dokumentasi.

\section{Teknik Analisis Data}

Data penelitian yang mengungkap karakteristik belajar mahasiswa dianalisis dengan menggunakan teknik statistik komparatif deskriptif. Sedangkan data hasil penelitian yang berupa dokumentasi hasil prestasi belajar mahasiswa dianalisis dengan cara membandingkan rata-rata hasil belajar mahasiswa bidikmisi dan reguler dengan melihat juga standar deviasi dan nilai IPK tertinggi - terendah mahasiswa.

\section{HASIL DAN PEMBAHASAN}

\section{Hasil Penelitian}

\section{Karakteristik mahasiswa bidik misi}

Sikap belajar mahasiswa bidik misi yang termasuk dalam kategori baik sebanyak $82,14 \%$, cukup baik $17,86 \%$, kurang baik $0 \%$, Tidak baik $0 \%$ (tabel 2). Minat belajar 
mahasiswa bidik misi yang termasuk dalam kategori tinggi sebanyak $100 \%$, cukup tinggi $0 \%$, kurang tinggi $0 \%$, Rendah $0 \%$ (tabel 2). Sedangkan motivasi belajar mahasiswa bidik

Tabel 2. Sikap, Minat, dan Motivasi Belajar Mahasiswa Bidik Misi

\begin{tabular}{|c|l|c|c|c|}
\hline No & \multicolumn{1}{|c|}{ Kategori } & Sikap belajar & Minat belajar & Motivasi belajar \\
\hline 1 & Baik (76-100\%) & $46(82.14)$ & $56(100)$ & $53(94.64)$ \\
\hline 2 & Cukup baik (56-75\%) & $10(17.86)$ & $0(0)$ & $3(5.36)$ \\
\hline 3 & Kurang Baik (40-55\%) & $0(0)$ & $0(0)$ & $0(0)$ \\
\hline 4 & Tidak Baik (<40) & $0(0)$ & $0(0)$ & $0(0)$ \\
\hline \multicolumn{2}{|c|}{ Jumlah } & $56(100)$ & $56(100)$ & $56(100)$ \\
\hline
\end{tabular}

Sikap belajar mahasiswa bidik misi yang baik $(82,14 \%)$ diikuti dengan beberapa strategi yang disusun supaya kuliah dapat selesai sebelum beasiswa bidik misi habis. Strategi tersebut antara lain (1) mendapatkan IPK >3 setiap semester, (2) mengerjakan tugas tepat waktu, (3) merencanakan skripsi lebih awal, (4) tidak menyia-nyiakan waktu dan lulus semua mata kuliah, (5) berusaha selalu mengikuti perkuliahan, (6) mengikuti ujian praktik dengan baik, (7) membuat laporan praktik dengan baik, (8) rajin beribadah, dan (9) menjaga hubungan baik dengan dosen. Selanjutnya, minat mahasiswa untuk menekuni program studi PT. Otomotif di FT UNY juga baik (100\%). Hal ini terjadi karena mahasiswa memiliki sendiri program studi yang ditekuni (90\%), sedangkan yang memilih karena pilihan orang tua jumlahnya sedikit (10\%).

Mahasiswa bidik misi mayoritas (60\%) sudah memiliki visi tentang profesi yang ingin diraih setelah menyelesaikan studi di pendidikan teknik otomotif FT UNY. Mahasiswa berharap dapat meniti karir sebagai guru, kepala bengkel otomotif, desainer misi yang termasuk dalam kategori tinggi sebanyak $94,64 \%$, cukup tinggi $5,36 \%$, kurang tinggi 0\%, Rendah 0\% (tabel 2). otomotif, dan mengembangkan usaha dibidang otomotif secara mandiri.

\section{Prestasi Hasil Belajar Mahasiswa Penerima Mahasiswa Bidikmisi dan Mahasiswa non Bidikmisi}

Prestasi belajar mahasiswa bidik misi dan non bidik misi (S1)

Data prestasi mahasiswa S1 PT. Otomotif FT UNY yang menerima beasiswa bidik misi dan tidak menerima bidik misi (tabel 3) menunjukkan bahwa prestasi mahasiswa penerima bidik misi lebih baik dibandingkan dengan mahasiswa yang tidak menerima beasiswa bidik misi baik di tahun I $(3,30 / 3,02)$ dan tahun II $(3,33 / 3,18)$.

Mahasiswa yang mempunyai IPK tertinggi dan terendah di kelas S1 Pendidikan Teknik Otomotif FT UNY tahun I adalah mahasiswa yang tidak menerima beasiswa bidikmisi (3,90 dan 2,76). Sedangkan mahasiswa S1 di tahun ke-2 yang mendapatkan prestasi tertinggi dan terendah juga mahasiswa non bidik misi $(3,72$ dan 2,56).

Tabel 3. Data Prestasi Belajar Mahasiswa Bidik Misi dan Non Bidik Misi (S1)

\begin{tabular}{|c|l|c|c|c|c|}
\hline \multicolumn{2}{|c|}{ Tahun/mahasiswa } & Tertinggi & Terendah & Rata-rata & SD \\
\hline \multirow{2}{*}{ I } & Bidik misi & 3,13 & 2,75 & 3,30 & 0,25 \\
\cline { 2 - 6 } & Non bidik misi & 3,90 & 2,33 & 3,02 & 0,33 \\
\hline \multirow{2}{*}{ II } & Bidik misi & 3,24 & 2,76 & 3,33 & 0,24 \\
\cline { 2 - 6 } & Non bidik misi & 3,72 & 2,56 & 3,18 & 0,28 \\
\hline
\end{tabular}


Prestasi belajar mahasiswa bidik misi dan non bidik misi (D3)

Mahasiswa D3 yang mendapatkan beasiswa bidik misi dimulai pada tahun ajaran 2013/2014 (tahun I). Berdasarkan data yang ditunjukkan pada tabel 4, rata-rata prestasi mahasiswa bidikmisi program D3 Teknik Otomotif FT UNY lebih baik $(2,99)$ dibandingkan dengan rata-rata prestasi mahasiswa D3 non bidik misi (2,93). IPK tertinggi diperoleh oleh mahasiswa non bidik misi $(3,57)$, akan tetapi IPK terendah juga didapatkan oleh mahasiswa non bidik misi $(2,25)$.

Berdasarkan data prestasi belajar tersebut (tabel 4), dapat disimpulkan bahwa kemampuan mahasiswa bidik misi lebih merata $(\mathrm{SD}=0,20)$ dibandingkan dengan mahasiswa non bidik misi $(\mathrm{SD}=0,28)$. Akan tetapi juga dapat disimpulkan bahwa masih terdapat mahasiswa berprestasi kurang dari yang diharapkan $(<2,75)$.

Tabel 4. Data Prestasi Belajar Mahasiswa Bidik Misi dan Non Bidik Misi (D3)

\begin{tabular}{|c|l|c|c|c|c|}
\hline \multicolumn{2}{|c|}{ Tahun/mahasiswa } & Tertinggi & Terendah & Rata-rata & SD \\
\hline \multirow{2}{*}{ I } & Bidik misi & 3,29 & 2,73 & 2,99 & 0,20 \\
\cline { 2 - 6 } & Non bidik misi & 3,57 & 2,25 & 2,93 & 0,28 \\
\hline
\end{tabular}

\section{Pembahasan}

\section{Karakteristik Mahasiswa Penerima Beasiswa Bidikmisi}

\section{Sikap belajar}

Sikap belajar mahasiswa bidik misi yang termasuk dalam kategori baik sebanyak $82,14 \%$, cukup baik $17,86 \%$, dan tidak ada yang termasuk dalam kategori kurang baik dan tidak baik. Berdasarkan analisis terhadap jawaban yang diberikan oleh mahasiswa bidik misi, terlihat bahwa mayoritas mahasiswa bidik misi $(86,7 \%)$ sangat bangga bisa menjadi mahasiswa Pendidikan Teknik Otomotif dan akan belajar sebaik-baiknya untuk bekal di masa depan. Perasaan bangga yang dirasakan oleh sebaian besar mahasiswa bidik misi cukup beralasan mengingat persaingan seleksi masuk UNY cukup ketat. Perasaan tersebut diharapkan mampu memotivasi dan meningkakan minat belajar, karena dapat diasumsikan bahwa ketika seseorang bangga dan puas dengan apa yang dia lakukan, maka dia akan termotivasi melakukan yang terbaik supaya berhasil (Hamidah, Rahmawati, \& Jaedun, 2013; Suwati, 2013).

Aspek selanjutnya adalah sikap terhadap tantangan yang muncul dalam perkuliahan.
Seluruh responden $(100 \%)$ menyatakan sangat bersemangat dan cukup bersemangat, tidak ada yang kurang bersemangat menghadapi tantangan. Hal ini menunjukkan bahwa mahasiswa terbuka terhadap tantangan yang muncul dan memiliki semangat untuk menyelesaikan tantangan tersebut. Selain semangat menghadapi tantangan, tentunya mahasiswa hendaknya memiliki target perkuliahan dan berusaha memenuhi target yang dicanangkan. Ketika sesorang mahasiswa memiliki target jelas, hal tersebut akan meningkatkan motivasi untuk meraihnya (Cauley \& McMillan, 2010; Nash, McGregor, \& Prentice, 2011). Sehingga akan memunculkan sikap-sikap yang berguna untuk mencapai target tersebut.

Fenomena lain yang sering dialami mahasiswa pada umumnya adalah perasaan bosan dan kesulitan belajar. Kedua indikator tersebut memperoleh variasi data yang cukup menarik. Pada aspek kebosanan, 17 mahasiswa menyatakan tidak pernah dan jarang merasakan kebosanan dalam perkuliahan. Hal ini mengindikasikan mahasiswa menjalani perkuliahan dengan baik dan antusias. Namun, cukup banyak mahasiswa (39) yang cenderung lebih sering merasakan kebosanan dalam 
kegiatan perkuliahan. Pada dasarnya, kebosanan dalam suatu aktifitas memang hal wajar. Kebosanan dalam perkuliahan memang dapat disebabkan beberapa hal, antara lain materi perkuliahan, metode pembelajaran, tenaga pengajar atau memang mahasiswa yang tidak berminat mengikuti perkuliahan (Poerwati, 2010). Namun, faktor yang sering terjadi adalah metode pembelajaran yang cenderung monoton sehingga diperlukan metode pembelajaran yag lebih variatif (Tiwan \& Leman, 2013).

Selain masalah kebosanan, masalah lain yang juga banyak dialamai mahasiswa adalah kesulitan belajar dan waktu studi yang terbatas karena jumlah beasiswa juga terbatas. Salah satu penyebab banyaknya yang kerap mengalami kesulitan belajar adalah karena cukup banyak mahasiswa yang berasal dari SMA. Sedangkan strategi yang disusun oleh mahasiswa tersebut untuk mengatasi lama waktu studi yang terbatas antara lain: memperoleh IPK > 3, mengerjakan tugas tepat waktu. menyusun skripsi lebih awal, tidak menyia-nyiakan waktu dan lulus semua mata kuliah, selalu mengikuti perkuliahan dan ujian dengan baik, membuat laporan dengan baik, rajin beribadah, dan mempunyai hubungan yang baik dengan dosen (tidak bermasalah).

\section{Minat Belajar}

Berdasarkan data hasil penelitian, seluruh $(100 \%)$ mahasiswa bidikmisi jurusan Pendidikan Teknik Otomotif memiliki Minat belajar yang cenderung masuk dalam kategori tinggi. Hal ini ditandai dengan selalu antusias mengikuti perkuliahan dan serius (fokus) menyelesaikan kewajiban perkuliahan. Proses perkuliahan dan berbagai kewajiban yang dilakukan mahasiswa bukanlah proses yang mudah. Ketika mahasiswa antusias melakukannya, maka tidak diragukan lagi bahwa mahasiswa tersebut memiliki minat belajar yang tinggi.

Perkuliahan di jurusan Otomotif FT UNY mensyaratkan minimal kehadiran (75\%) mahasiswanya. Meskipun telah memenuhi syarat minimal, mahasiswa akan tetap ingin mengikuti perkuliahan agar ilmu dan wawasan terus bertambah dan ingin selalu melaksanakan kuliah dengan sebaik-baiknya. Salah satu penyebab tingginya minat belajar, mengikuti perkuliahan dan mengerjakan kewajiban perkuliahan adalah karena menjadi mahasiswa Pendidikan Teknik Otomotif merupakan pilihan sebagian besar (90\%) responden. Sehingga, responden memiliki kesadaran dan motivasi pribadi untuk melaksanakan yang terbaik pada apa yang telah dipilih (Setiaji, 2015). Selain itu, diperoleh juga informasi mengenai cita-cita responden. Responden memiliki cita-cita yang bervariasi, antara lain: guru, Workshop head ATPM, automotive designer, wirausaha bidang otomotif, bahkan ada yang bercita-cita menjadi menteri perhubungan. Cita-cita tersebut berhubungan erat dengan apa yang didapatkan dalam perkuliahan, artinya, para mahasiswa telah memahami apa yang dilakukan dan manfaatnya. Hal itu hanya dapat dialami oleh orang yang memiliki minat yang besar. Sehingga, daat disimpulkan bahwa mahasiswa Bidikmisi jurusan Pendidikan Teknik Otomotif memiliki minat belajar yang tinggi. Hal itu ditandai dengan antusias mengikuti perkuliahan, fokus menyelesaikan kewajiban perkuliahan, melaksanakan perkuliahan dengan baik dan memiliki cita-cita yang relevan dengan apa yang didapatkan dalam perkuliahan (Setiaji, 2015).

\section{Motivasi Belajar}

Pada variabel motivasi belajar, diperoleh data bahwa sebagian besar $(94,64 \%)$ mahasiswa bidik misi termasuk dalam kategori tinggi dan sisanya $(5,36 \%)$ masuk pada kategori cukup tinggi. Hal itu ditandai dengan rutinitas belajar yang baik, tidak membuang-buang waktu dan bersungguh-sungguh menyelesaikan tugas kuliah. Salah satu penyebab mahasiswa melakukan hal tersebut adalah karena ingin berprestasi. Karena memang prestasi hanya dapat diraih jika mampu memanfaatkan waktu sebaik-baiknya untuk belajar dan menyelesaikan tugas perkuliahan (Puspitasari, 2013). Untuk meraih prestasi yang diinginkan, baik secara langsung maupun tak langsung, mahasiswa akan menemui tantangan-tantangan. Tinggi 
rendahnya tantangan memang tergantung dengan pribadi yang mengalaminya. Sehingga, yang tepenting adalah bukan setinggi atau semudah apa tantangan itu, tetapi upaya apa yang akan dilakukan untuk menghadapi tantangan.

Selain tantangan, hambatan/kesulitan belajar kerap dialami mahasaiswa. Berdasarkan item angket, diketahui bahwa sebagian besar reseponden menyatakan berusaha menyelesaikan sebaik-baiknya dan selalu optimis bahwa permasalahan selalu dapat diselesaikan. Ini merupakan sikap seseorang yang memiliki motivasi belajar tinggi.

Indikator lain dari motivasi belajar adalah, pertanggungjawaban responden terhadap apa yang telah didapatkan dan apa yang akan dipersembahkan untuk masyarakat. Berdasarkan data hasil penelitian, diketahui bahwa usaha yang dilakukan untuk bertanggungjawab terhadap beasiswa yang diterima antara lain: aktif dalam forum mahasiswa bidik misi, selalu berusaha mendapatkan berprestasi yang tinggi, mengurangi beban orang tua, belajar dengan giat dan bersungguh sungguh, menyelesaikan studi sesuai jatah waktu yang diberikan, membuat alat yang berguna bagi masyarakatdan menggunakan uang beasiswa untuk kebutuhan akademik

Kesimpulan dari kajian di atas adalah dengan memberikan stimulus bahwa mahasiswa mendapatkan beasiswa yang dananya bersumber dari uang masyarakat, ternyata mampu menunjukkan bahwa mahasiswa memiliki motivasi tinggi yang ditandai dengan minat belajar yang tinggi, motivasi berprestasi, lulus cepat hingga termotivasi untuk membuat sesuatu yang bermanfaat bagi masyarakat umum.

\section{Hasil belajar mahasiswa mahasiswa bidikmisi dan mahasiswa reguler}

Prestasi mahasiswa bidik misi secara umum lebih baik daripada mahasiswa yang tidak menerima beasiswa bidik misi. Kemampuan yang dimiliki mahasiswa bidikmisi juga terlihat lebih merata. Akan tetapi masih terdapat mahasiswa beasiswa bidik misi dan non bidik misi yang memiliki IPK kurang dari 3,00. Dosen-dosen di jurusan pendidikan teknik otomotif perlu memberikan perhatian dan perlakukan khusus terhadap mahasiswa yang memiliki prestasi kurang dari rata-rata yang ditargetkan. Lebih khusus lagi diperlukan perhatian terhadap mahasiswa penerima beasiswa bidik misi. IPK yang kurang dari 3,00 dapat menyebabkan mahasiswa tidak dapat mengambil mata kuliah yang ditawarkan secara optimal dan akhirnya memerlukan waktu studi yang lebih lama.

\section{KESIMPULAN DAN SARAN}

Kesimpulan

Kesimpulan yang diperoleh dari penelitian ini adalah bahwa mahasiswa penerima beasiswa Bidikmisi memiliki karakter yang baik, hal itu dilihat dari aspek sikap kerja, minat dan motivasi belajar yang termasuk dalam kategori tinggi (sangat baik). Prestasi mahasiswa bidik misi juga lebih merata dibandingkan dengan mahasiwa non bidik misi, akan tetapi masih terdapat mahasiswa yang mendapatkan rata-rata IPK dibawah standar minimal jurusan yang dapat mengakibatkan mahasiswa tersebut tidak dapat mengambil mata kuliah secara maksimal disemester berikutnya.

Saran

Berdasarkan hasil penelitian dan pembahasan dalam penelitian tentang karakteristik dan prestasi mahasiswa bidik misi ini, disarankan supaya mahasiswa bidikmisi perlu selalu dipantau dan diingatkan untuk menyelesaikan kewajiban perkuliahannya karena beasiswa bidikmisi tidak sepanjang waktu kuliah tetapi hanya enam (6) semester untuk D3 dan delapan (8) semester untuk S1. Apabila mahasiswa tersebut bisa menyelesaikan kuliah tepat waktu, maka mahasiswa tidak perlu membayar uang kuliah dengan uang sendiri. 


\section{DAFTAR PUSTAKA}

Azwar, Saifuddin. (1998). Sikap Manusia. Yogyakarta: Pustaka Pelajar.

Cauley, K. M., \& McMillan, J. H. (2010). Formative assessment techniques to support student motivation and achievement. The Clearing House: A Journal of Educational Strategies, Issues and Ideas, 83(1), 1-6.

Danim, Sudarwan. (2004). Motivasi Kepemimpinan \& Efektifitas Kelompok. Jakarta: Rineka Cipta.

Efendi, A. (2011). Pembelajaran Sastra Profetik sebagai Media Pengembangan Karakter Siswa. Cakrawala Pendidikan, Jurnal Ilmiah Pendidikan, 30, 39-51.

Ellis, H. James. (1998). Psikologi Pendidikan. Jakarta: IKIP Jakarta.

Hamalik, Oemar. (1983). Metode Belajar dan Pembelajaran. Bandung: Sinar Baru.

Hamidah, S., Rahmawati, F., \& Jaedun, A. (2013). Pembelajaran soft skills terintegrasi bagi penumbuhan karakter pekerja profesional bidang Boga. Jurnal Kependidikan: Penelitian Inovasi Pembelajaran, 43(2).

Hasibuan, Melayu. (2003). Organisasi \& Motivasi Dasar Peningkatan Produktivitas. Jakarta: Bumi Aksara.

Hudoyono, Herman. (1988). Mengajar Belajar Matematika. Jakarta: Depdikbud.

Hurlock, Elzabeth. (1996). Perkembangan Anak. Terjemahan: Erlangga.

Kemendikbud. (2014). APK/APM PAUD, SD, SMP, SM dan PT 2013/2014 (termasuk
Madrasah dan sederajat). Pusat data dan statistik pendidikan, Kemdikbud. Jakarta

Kartono, Karmi. (1982). Teori Keperibadian. Bandung: Alumni.

Kharisma, N., \& Latifah, L. (2015). Pengaruh motivasi, prestasi belajar, status sosial ekonomi orang tua dan lingkungan teman sebaya terhadap minat melanjutkan pendidikan ke perguruan tinggi pada siswa kelas XII kompetensi keahlian akuntansi di SMK Negeri se-kota Semarang tahun ajaran 2014. Economic Education Analysis Journal, 4(3).

Lidyasari, A. T. (2016). Membangun karakter mahasiswa yang bertanggung jawab melalui problem-based learning (PBL). Prosiding seminar nasional "Meneguhkan peran penelitian dan pengabdian kepada masyarakat dalam memuliakan martabat manusia”. LPPM UNY.

Nash, K., McGregor, I., \& Prentice, M. (2011). Threat and defense as goal regulation: From implicit goal conflict to anxious uncertainty, reactive approach motivation, and ideological extremism. Journal of personality and social psychology, 101(6), 1291.

Poerwati, T. (2010). Pengaruh Perilaku Belajar dan Motivasi Terhadap Prestasi Akademik Mahasiswa Akuntansi di Universitas STIKUBANK (UNISBANK) Semarang. Dinamika Sains, 8 (16).

Purwanto, N. A. (2011). Strategi Bersaing Dalam Bisnis Pendidikan. Jurnal Manajemen Pendidikan, 7(1).

Puspitasari, W. (2013). Hubungan antara manajemen waktu dan dukungan sosial dengan prestasi akademik mahasiswa yang bekerja. EMPATHY Jurnal Fakultas Psikologi, 2(1). 
Sardiman. (1996). Interaksi dan Motivasi Belajar. Jakarta: Rajawali Press.

Sardiman. (2004). Interaksi \& Motivasi Belajar Mengajar. Jakarta: Rajagrafindo Persada

Sarwono, Sarlito Wirawan (1976). Pengantar Umum Psikologi. Jakarta: Bulan Bintang.

Satryawan, E., Nuridja, I. M., \& Suwena, K. R. (2016). Studi komparatif prestasi belajar mahasiswa antara penerima beasiswa dengan tidak penerima beasiswa di Fakultas Ekonomi dan Bisnis Universitas Pendidikan Ganesha angkatan 2011. Jurnal Pendidikan Ekonomi Undiksha, 7(2).

Setiaji, K. (2015). Pilihan Karir Mengajar Mahasiswa Pendidikan Ekonomi (Kajian Motivasi Karir Mengajar, Career Self Efficacy, Status Sosial Ekonomi, Minat menjadi Guru Terhadap Prestasi Akademik). Dinamika Pendidikan Unnes, 10(2).

Slameto. (1991). Belajar dan Faktor-Faktor Yang Mempengaruhinya. Jakarta: Rineka Cipta.

Sudjana, Nana. (1989). Cara Belajar Siswa Aktif dalam Proses Belajar Mengajar. Bandung: Sinar Baru.

Suwati, Y. (2013). Pengaruh Kompensasi dan Motivasi Kerja Terhadap Kinerja Karyawan Pada PT. Tunas Hijau Samarinda. Jurnal Ilmu Administrasi Bisnis, 1(1), 41-55.

Syah, Muhibbin. (1996). Psikologi Pendidikan dengan Pendekatan Baru. Bandung: Remaja Rosdakarya.

Tiwan, T. \& Leman, A. (2013). Penerapan pembelajaran semi riset untuk meningkatkan pemahaman mahasiswa tentang sifat-sifat bahan teknik pada pembelajaran bahan teknik dasar. Jurnal
Pendidikan Teknologi dan Kejuruan, 21(3).

Walgito, Bimo. (1981). Bimbingan dan Penyuluhan di Sekolah. Yogyakarta: Fakultas Psikologi UGM.

Waskito, D., \& Azizah, K. (2013). The Effects of Granting Students Scholarships on the Learning Motivation of the Students of the Economics Faculty of Yogyakarta State University in 2012. Pelita-Jurnal Penelitian Mahasiswa UNY, 8(1).

Winkel, W.S. (1999). Psikologi pengajaran. Jakarta: Gramedia. 